\title{
Rezension zu: Ulrich Fellmeth, Pecunia non olet. Die Wirtschaft der antiken Welt (2008)
}

\author{
Ágnes Alföldy-Găzdac - Cristian Găzdac
}

The book, Pecunia non olet. Die Wirtschaft der antiken Welt, is an excellent work on the theory of economy for the Greek-Roman period of Antiquity. It details an approach on the complex mechanisms of the economy of the ancient Mediterranean. Although the book is designed for an overall view on the ancient economy, this achievement turns into a treaty on economic thinking and the perception of the economic structures by the ancient communities. The book analyzes the period from Archaic Greece through the end of the Late Roman Empire (c. $8^{\text {th }} \mathrm{BC}$ to c. $4^{\text {th }} \mathrm{AD}$ ).

The book is chronologically and thematically organized. Ulrich Fellmeth uses ancient sources, ancient writers and epigraphic evidence, as well as iconographic and archaeological sources to illustrate his theories. He analyzes ancient authors from the earliest Greek sources to the first Christian authors (e.g. Lactantius). He uses such sources to decrypt each economic system for archaic and classical Greece, hellenistic Mediterranean, republican Rome, and, finally, the Roman Empire. Each chapter, with its subchapters, discusses individual chronological periods, and illustrates the issues using ancient sources and reviews the attitudes of philosophers concerning the economy of their time. The subchapters consist of reflections based on various personalities and known ancient works, such as Hesiod, Pericles, Pasion, Xenophon, Cato, Tiberius Gracchus, Verres, Pliny the Younger, etc. The sources are presented in the socio-economic context of their corresponding historical period.

Chapter One introduces useful sources to sketch out the ancient economy and the economic way of thinking. The author considers impact of archaeological evidence as limited, except to prove the existence of economic activities, such as painted pottery, funerary monuments, or other items from the archaeological record. Fellmeth suggests that the best information is from inscriptions, papyri, coinage, and ancient authors. From his point of view, inscriptions papyri and coinage are more expressive, however, the ancient authors offer the best information.

Fellmeth discusses the dogma of the Greek philosophers, Aristotle and Plato, and this referral to ancient philosophers and writers threads through the discussion of the economics of the later periods. The original idea suggests that landowners who practiced agriculture and trade were good and honorable people, the kaloi kagatoi (felicitous). Others who earned their living through work, such as craftsmen, traders and peasants, are people without civic values. The difference between the daily economic reality of work as a necessity, and the elite condescension towards labor was a paradox noticed by the ancients, such as Plutarch and Lucian.

The author discusses the main features of the Iron Age economy. His ideas of the early Iron Age are supported with quotations from Homeric texts. The concept of oikos, or the household, was the main form of social organization and created the kernel of economy based on autarchy. There was no market, and surplus was hoarded to increase and cement social prestige. Raw materials and luxury goods, which were not produced at a household level, were acquired through interactions, mainly gift exchanges. The main sources of income were war, plunder, and land ownership. 
Trade was considered a dishonorable activity, and done by outsiders, like the Phoenicians.

The following sub chapter presents the economic mentality of yeomen in the $7^{\text {th }} \mathrm{c}$. BC, and, by using Hesiod, the author highlights the idea that agricultural work is the only legitimate way to welfare. In contrast to the elite warrior society of Homer, Hesiod's farmers hated war, and the resulting plunder, because it jeopardized the products of their labor. It is during this time period that ancient authors mention the idea of rational organization of production and of households, which was the only way that yeomen survived (p. 28) under the pressures of "noble" society.

The next section describes socio-economic changes in the Greek world starting with the $7^{\text {th }}$ century BC. The colonization of the Mediterranean shores resulted from the lack of agricultural land and food. Internal social movements, such as tyrannical regimes, led to the polis, or an autonomous form of government of the city-state. The burst of trade, however, was the result, but not the aim of colonization, and few colonies were established based purely on commercial needs, such as Cumae, Massalia, and Naukratis. The establishment of a central market, agora, was the catalyst in the change from the autarchic to the classical economy of the polis, which was closely linked to the change in warfare techniques that resulted in the creation of the hoplite phalanx which depended on individuals providing their own military equipment. The introduction of coinage did not have a sudden positive aspect on the commerce, because, initially, only high denominations were issued, perhaps for soldiers' pay or hoarding. There is no evidence for small transactions, however, by the mid $6^{\text {th }}$ century $\mathrm{BC}$, coinage was indispensable in economic transactions.

The following discussion focuses on private economy and uses as its foundation a Plutarch quotation regarding the progressive thinking of Pericles. A frequent topic of the Sophists, oikeia pragmata, had a decisive impact on the mentality of the polis citizens. Fellmeth uses select examples from Demosthenes' Orationes, to draw out various models of economic thinking in classical Athens. He identifies different concepts on investment and resulting profits (see the tables and graphs, pp. 44, 46-47).

Ulrich Fellmeth emphasizes weak points of state economy such as the lack of fiscal economy and the absence of budgets or long-term financial planning in classical Athens. The government practiced a daily economy and did not invest any surplus of money. This phenomenon existed because the Athenian government was a citizens' community, and the state did not have its own assets (p. 52). As a result, the package of economic reforms suggested by Xenophon, such as socio-political interests, foreign investments, social integration of trading investments in the rental of slaves for silver mining, the covering of investments with new taxes according to individuals' incomes, etc., represents a radical change in the economic way of thinking, which would be developed within Hellenistic states.

The domination of the big land properties, the development of a rational production of luxury goods, the orientation towards a market economy, and an intensive monetary economy characterizes the Hellenistic period. Ptolemaic Egypt is an excellent example on the evolution of the state economy because of the preserved documentation of information on various branches of the economy. One must be 
cautious, however, and remember that the types of economical patterns are not the same for all regions in the Mediterranean during the Hellenistic period. The model of temple economy in Egypt influenced the state economy As opposed to the polis economy in classical Greece, the Ptolemaic Egyptian state was the omnipotent element in economy. Private property was extremely limited, because the crown owned the land and held a monopoly on cattle breeding, mining, fishing and hunting, and the main branches of industry, olive oil, leather, textiles, glass, papyri, and metallurgic production. Although, the state controlled prices and eliminated competition, it was not a complete autarchy because many raw materials and nonnative items for many industries had to be imported. Profits from state-controlled industries, taxes and contributions, and custom taxes on the import-export merchandise (up to $50 \%$ of the product value) ensured the state a safe and constant income. The Egyptian population was obligated to annually declare the number of household members and property. The state-controlled economy of Ptolemaic Egypt required a large bureaucratic machine that demonstrated a planned political economy in the true modern definition. Rome took over this economic system by transforming Egypt in the "royal domain." The private enterprises were possible only in those fields that required a certain risk: taxes, the large enterprises (doerai) held by high positioned dignitaries, and banking affairs.

Ulrich Fellmeth analyzed the monetary economy of Hellenistic Egypt because it adopted the Phoenician monetary system, in direct contrast to other Hellenistic Greek states ruled by diadochs, and created a banking economy. The state held the monopoly on banks headquartered in Alexandria, and the network of state banks included every important town of Egypt and some villages. Individuals made payments, bank deposits, and money transfers through banks. The entire population of hellenistic Egypt, not just the very rich, adopted the banking system. The ability to loan funds was chartered to private banks, rich individuals, and temples, and the interest could reach as high as $18 \%$. A papyrus document, known as the "Zenon archive," details the complex economy of Ptolemaic Egypt. Zenon was the land agent of Apollonios, who was the minister of finances and economy during the reign of Ptolemy II Philadelphos in the mid $3^{\text {rd }}$ century BC. The papyrus notes the work process at a dorea and the trade of its end-products. Fellmeth demonstrates the duality of the economic aims of the Ptolemaic administration, the quest for large profits balanced by the preservation of the politcal welfare of the state. Unfortunately, economic crisis appeared in 2nd c. BC Ptolemaic Egypt due to high taxes and government corruption.

The author discusses the economic development and changes that occurred as a consequence of Roman expansion, such as the concentration of provincial wealth in the hands of senators and business men, the importation of slaves as a result cheaper paid labor, an increase of agricultural work, and the rise of large agricultural-based estates in Italy. The appearance of skilled slaves determined the increase of industrial capacity in towns. Trade was encouraged by the introduction of coins around $300 \mathrm{BC}$, although products were traded on local markets, except for items, such as: fine pottery of Arezzo or from southern Gaul; metal vessels, textiles, jewelry, or special, imported luxury goods (e.g Egyptian papyrus).

Unlike the traditional portrait of Cato, the author presents this enemy of extortionists as a true business manager. This homo novus, described by ancient 
authors as a fancier of agriculture and a shrewd investor, was a skillful "businessman," who invested capital in zero risk tasks, such as lakes, thermal springs, pastures, slaves who were trained and then sold, as well as unsecured investments such as insurance. The Lex Claudia, $218 \mathrm{BC}$, was created to prohibit the senatorial class from investing in commercial businesses and banks. Taxes on luxury items attempted to control the Roman social structure and, as a result, increased the state income.

A subchapter reviews the complex social and economic issues of the Roman Republic: the material and social differences of the senatorial oligarchy; the use of slaves in all aspects of Roman economy; the economic crisis of Roman farmers who were forced to relocate to towns and cities because of the loss of their properties; and the increase of unemployed Romans inhabiting towns and cities. In conjunction with his discussion of the changes in the Roman economy, the author highlights the ideas of Tiberius Gracchus who separated himself from the social and moral obligations of his class more than any other Roman politician. T. Gracchus attempted to reform the difficult issues that threatened Roman society.

Another matter of socio-economic nature in the republican Rome was the corruption and the arbitrary exploitation of resources in the provinces. The only sources available of the $70 \mathrm{BC}$ scandal involving Verres are the documents of the prosecution, represented by Cicero. He accused the governor of Sicily of corruption of justice, malversion of public positions and taxes, and theft of art work from private persons. Ulrich Fellmeth considers that this image of the marauder of the Roman elite was given a disadvantage to the state economy and stopped the development of the private economy. Both senators and equites contributed to the provinces' exploitation.

Fellmeth analyzes the writings of M. Terentius Varro and Columella who commented on agriculture in the Roman Republic, and suggests the existence of many references from other ancient authors on this subject whose discussions center around the work division between town (the marketplace) and the rural area (as the production place). The stultification of costs, the increase of production and the orientation towards market were signs that, at least, there was a rational economic thinking on agriculture with a single aim: the increase of profit.

The author reviews the main features of changes following the change from the Republic to the Empire. The famous pax Romana was not only a substantial demographic boom, but also an increase of property warranty and security. The constant improvement of the infrastructure (roads, harbors etc.) made merchandise circulation easier. In the author's view, there was a direct connection between a demographic increase and a flourishing economy. There also seems to be a role played by the army in regional economies, in relation to the army supply and the buying capacity of soldiers. For the frontier provinces, it resulted in an economic boom (p. 124). Fellmeth also presents the negative impact on economic development and offers representative examples, which were expensive long distance trade (the transportation for more than $100 \mathrm{~km}$ raised the costs of a product in accordance with the mode of transportation: $1.3 \%$ by sea, $6.4 \%$ by river, $44 \%$ by camel caravan, $55 \%$ by cart), poor money supply, absence of machines in the production process, etc. 
The author elucidates aspects such as organization of the agricultural production, partition between land, capital and labor, and agricultural techniques. It is difficult to estimate the quantitative production as no documentation survives. It is estimated that $80 \%$ to $90 \%$ of the Empire's population lived in the rural areas and was involved in the agricultural works. During the Empire, extension of fields took place in Gemania, Gallia, Hispania and Africa. The enhancement of production occurred through different systems to work the fields: crop rotation every two to three years and the use of dung. However, agriculture had a low enhancement (three to five times) in comparison with the normal productivity of fields in the $19^{\text {th }}$ century (five to ten times) or today (thirty times). The most productive areas were the Black Sea, Northern Africa, Egypt and Sicily because of their more temperate climates. Owners invested in fruit trees plantations, vineyards, olive trees or cattle breeding as these options had good potential as income sources.

Population increases also led to the intensification of industrial production. The rise of market demand and the accessibility of raw materials helped the appearance of big enterprises in the fields of textiles, glass, metallurgy, etc. Specialization in various branches of industry increased the possibilities for higher profits. Fellmeth briefly analyzes fine pottery from production centers in southern Gaul and gives a clue on the success which eliminated competitors who made Aretine ware, based on a finer quality of clay, a better distribution from the centers to the marketplaces, and the implementation of cheaper river transportation from Gaul towards northern and western markets. Industrial specialization is also demonstrated by the 200 known professions from Roman inscriptions, and by 500 Latin expressions regarding various handicraft jobs. The author addresses the question of Roman industry's dislike of technical innovations and the avoidance of known wind and steam powered machines. He also suggests that bankers lacked the desire to invent in industry. Another possible explanation offered by the author is one of economic nature: the bankers were not interested to invest in industry.

Ulrich Fellmeth briefly describes the Roman monetary system in the early Empire (the Principate). The system was based on the "metallism" principle where the coin value is equal to the intrinsic market value of precious metals, gold and silver, and the value of the small denominations, copper, orychalcum, and bronze are established in relation to the metals of higher values. He draws attention to the gold and silver fluctuations on the market (e.g. the strong injection on market with gold after the Dacian wars in the time of Trajan). Fluctuations of the value of the precious metals were controlled by the monopolies of the gold and silver mines (a large majority of mines were government property by the reign of Tiberius), and adjustments in the weight and the purity of the silver and gold. Prices were stable until the $3 \mathrm{rd} \mathrm{c}$. AD when the debasement of the coinage caused inflation. Fellmeth reveals the errors in the imperial monetary policy by the emperors by using the writings of the Roman historians. Suetonious states that Augustus minted more coins for circulation, while Tacitus identifies that the small quantity of coins in circulation during the reign of Tiberius led to a decrease in prices and deflation. The lack of money was a consequence of various elements: a negative balance of external trade (a loss of 7\% from the state budget), the stipends paid to barbarians, the private and state hoarding and the bank deposits (p.141). New monetary issues (estimated to $20 \%$ annually) were not minted in large quantity and could not cover the need of coinage on the market. 
Numerous banks in Rome, and elsewhere in Italy, attest to the high level of monetization and development of banking. The Hellenistic banking system was taken over by the Romans but with little change. Fellmeth discusses the existence of banking transactions, similar to modern banks, without the physical movements of money in Egypt where taxes were paid at local banks and the sum was transferred to the central bank in Alexandria. It is likely that such transactions were more common in the eastern provinces than the western ones because of the long banking tradition already in place. The author underlines the regional patterns of the development of industry, trade and coin circulation.

The most interesting chapter discusses the analysis of the iconography of funerary monuments to establish the evolution of self-representation and social appraisal of craftsmen. Fellmeth discusses the idea that, in regards to social prestige, craftsmen were never a homogenous group. Itinerant workers employed for wage were at the bottom of scale while independent craftsmen who owned their own workshop and a small shop were considered to be part of the Roman middle class. The ability to change one's social status is exemplified by a funerary monument from Fossano, near Torino, which boasts that its owner, a faber, or wheelwright, had been an $a b$ asse quaesitum, a relatively poor position, but eventually became a sevir augustalis, a higher position. The affiliation with guilds, collegia, included material support, social prestige and appreciation. There is no certain evidence that these collegia were in charge of production organization, quality control, price control, or protection against competition. Despite the negative appraisal from the higher societal castes, long distance merchants (negotiatores, mercatores frumentarii) were wealthy and influential people who held important positions within local communities. A geography book on trade published in late antiquity, Expositio totius mundi et gentium, mentions Syrian towns on the Mediterranean coast which "export textiles all over the world," and the people "are rich from all points of view." The merchants" attitude towards profit is well demonstrated by Pompeian graffiti: salve lucrum (Hail, Profit!) or lucrum gaudium (Profit is joy!).

The chapter "The emperor and the food supply of Rome" focuses on the state commission, praefectus annonnae, established by Augustus with the purpose of assuring the Roman food supply in the time of crisis. Fellmeth addresses whether the types of measures taken by emperors to indicated a deliberately planned political economy of Roman state. He uses a series of significant examples of the provision of wheat and construction of public works to provide the answer. Wheat prices were maximized in order to stifle the increase of costs, while in crises starvation was averted by means of liberalitas, offerings to the people from the emperor's personal accounts. There is some evidence for measures with long term effects. Claudius I gave privileges to wheat merchants to ensure a constant wheat (grain) supply for Rome. Emperors established additional measures, such as road and bridge constructions, establishment of mansios (lodgings), and military protection against robbers. Fellmeth considers these activities as part of an established conception of the Roman political economy. Emperors did not interfere in the economy aside from general actions and exceptional rules in the times of crisis. One exception was the organization of production in Egypt because the province was the private property of the emperor. The Roman Empire was a market network where almost all of the components regulated themselves. In comparison with the modern economy, the passive attitude of the Roman state could be called a liberal political economy. Roman emperors, 
however, did not know how this functioned, thus their reactions to the crisis was exploratory or naive (p. 158).

Fellmeth uses a letter by Pliny the Elder, which documents the sale of property in Umbria, to demonstrate the various types of agricultural enterprises. The author identifies the following categories: family households, villae, big villae (over $250 \mathrm{ha}$ ), and latifundia. He also analyzes two types of rent. The rent of land based on a certain percentage from products had a positive impact on the increase of production (more specific in the western parts in the first two centuries AD) and the type of rent for money. The second type was more risky as it gave the owner a chance for a higher profit but there was a possibility of financial ruin. Fellmeth highlights the changes in the economic mentality through time from Columella to Pliny the Younger.

A demographic decrease and the lack of a labor force (agri deserti) was the result of wars and pestilence and resulted in a negative impact upon town supplies. Army costs rose significantly and caused the increase of taxes that pressured urban inhabitants. Buying power decreased and resulted in the decline of craft production and long distance trade. Fellmeth analyzed the series of Diocletian's reforms, such as his monetary reform and his the Price Edict. He reviewed the efficiency and the impact of putting the economy at work. Diocletian's reign is defined by frequent interference by the state in the Roman economy (e.g. where the state has a direct interest the jobs were permanently given to the same family, the child had to take the job after father retired or died). A part of industry became property of state. The armour and uniforms were produced in state units. Pressure from the state was a feature of the late ancient economy, especially in the western provinces of the Empire.

The final chapter of the book is titled "The end: the ancient economy and the ancient homo economicus." Fellmeth addresses the importance of studying ancient economies and whether the study of ancient economies impacts only antiquarians. Ulrich Fellmeth believes that ancient economic practices are intrinsic to the study of modern economies as it allows recognition of the main features of modern economic behavior. Modern examples are quite eloquent. The rural European households the $19^{\text {th }}$ and the beginning of the $20^{\text {th }}$ centuries echoed autarchy similar to the "oikoseconomy" of archaic Greece (p. 176). The ancient Greek autarchic system was succeeded by the "polis-economy," while the 19th and 20th century autarchic economy was followed by an industrial economy. Both the ancient and modern autarchic economies are identified by work distribution and market production. Another example comes from monetary industry: The mentality of hoarding in ancient is compared to the modern practice of keeping low interest savings accounts.

One idea concerning modern theories of consumption is the conception of a "satisfier," who is a comfortable, passive consumer who is easy to convince, in contrast to the idea of the "optimizer," who is a cautious, economic consumer orientated towards efficiency. The author identifies the economic behavior of the "satisfier" among the wealthy structures of the Roman Empire. An example of a "satisfier" is Pliny the Younger who knew how to increase the efficiency of the agricultural works. He was, however, a comfortable agrarian with no interest for agriculture, and who was happy to have a limited but safe income (p. 177). Another question refers to guided state interference in the economy and if the interferences benefited or ruined the entire economy. The Hellenistic state economy (where the 
state laws oppressed the private initiative) and the Roman economy (when the state interfered only in moments of crisis) are opposite models of political economies (p. 178). According to Ulrich Fellmeth, the historiographic concept of "primitivism" of ancient economic thinking must be regarded as a specific pattern of a non-industrial mentality. Unlike the modern societies, where the economy is priority in an individual's life, in antiquity, man's life was guided by other values and the economic interest was not present in all the aspects of human existence.

The book was written in an academic style with specific language for modern economic theories and doctrines. The bibliography is presented at the end of book with select titles for each chapter. Unfortunately, this system does not allow the reader to delve deeper in the study of the topics discussed by the author. It is not known if the graphs presented in this book were the author's or if they were taken from other sources. Even with these small omissions, however, the book is a success in regard to the topic. The author gathered and synthesized information on a complex and large subject: the economy of antiquity. He answered the fundamental question if the ancient societies possessed an economic way of thinking and a political economy. We believe that the author used good arguments for each ancient period discussed. The author 's approach to social frameworks via ancient economics and his prudence in accepting theories are positive arguments to read Pecunia non olet, Die Wirtschaft der antiken Welt. 